\title{
Evolutionary Aspects of the Miogypsinidae from Azkand Formation (Oligocene-Miocene) in Kirkuk Area, Iraq
}

\author{
Imad M. Ghafor \\ Department of Geology \\ College of Science \\ Sulaimanya University
}

\author{
Qahtan A. Muhammed \\ Kirkuk Technical College \\ Kirkuk, Iraq
}

(Received 26/4/2006, Accepted 7/12/2006)

\begin{abstract}
The biometric analysis on Miogypsina from bioclastic limestone (Azkand Formation) in Kirkuk area, Iraq reveals that the evolutionary trend based on a distinct overall change in morphology of the nepiont, which change is in agreement with the principle of nepionic acceleration as defined by Tan Sin Hok,1936. The oldest species of Miogypsinoides represented by Miogypsinoides complanata and Miogypsinoides formosensis accompanied by the association Miogypsina gunteri which exhibit in the lower part of Azkand Formation of Late Oligocene age (Chattian). The early Miocene association of Miogypsina s.s. represented by Miogypsina gunteri-tani are often accompanied by Miogypsinoides. Most of these are close to Miogypsinoides bantamensis.
\end{abstract}

الظط التلوري لـ ـ Miogypsinidae) من تكون ازقند (الاوليجوسين - المايوسن) في

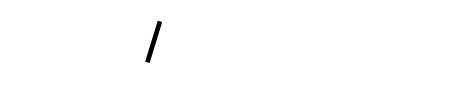

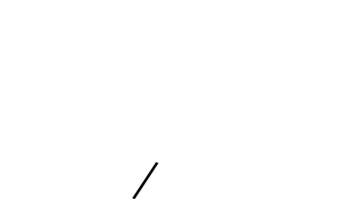

\author{
عمادمحمود غتور \\ قصم علوم الأرض/كلية العلوم \\ جلمعة السليمانية
}

\section{المالخص}

لن درلسة التحليل القيلي الحياتي للجنس (Miogysina) المأخود والمستحصل من التتبعلت للصخور الكلسية الحياتية المتمثلة بتكوين ازقند (اوليجوسن - مايوسين) من مطقة كركوك، العراق سيعكس الظط الظوري الرئيسي لها على لسلس التغيرات المميزة فيشكل وحهم الغرف الاولية وهذه

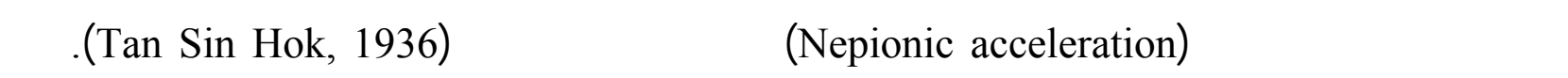

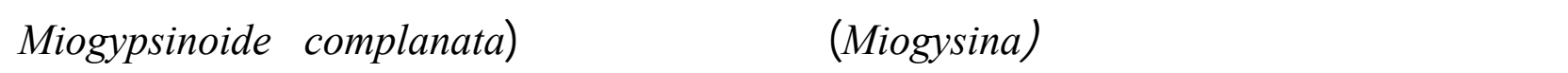
(Miogypsinoides formosensis للسفلي aن تكوين الأزقند (الاوليجوسين المتلخر) وان التجمعكت للجنس (Miogypsina) من المايوسين

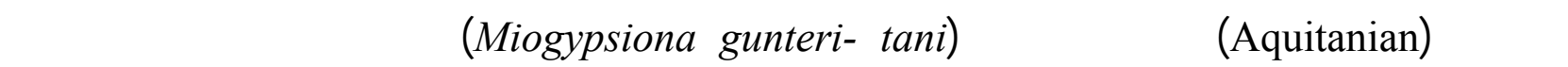
(Miogypsinoides) والتي على الأكثر تعود للنوع (Miogypsinoides bantamensis). 


\section{INTRODUCTION}

The succession of Miogypsina species in the Oligocene carbonate rocks (Azkand Formation) during the biometric analysis study on Miogypsinidae in Kirkuk area Iraq, provides us with unique proof for the general validity of the principle of the nepionic acceleration (Tan Sin Hock, 1936a) in the evolution of the Miogypsinidae. Most investigated Miogypsina association are derived from the Azkand Formation in Khabaz well-3 and Qarah Chauq Dagh sections (Fig.1). A major deviation from the earlier established evolution, Aquitanian occurrences of two morphometric units close to Miogypsinoides bantamensis, instead of only one. They were named Miogypsinoides I and II. This divergence from the overall line of evolution will be discussed in this paper.

The evolutionary patterns in our Miogypsina will be dealt with in more detail, which actually was the main purpose of our investigation. The morphometric series will be compared with the results of earlier published detailed studies on other Orbitoidal foraminifera and current evolutionary theories.

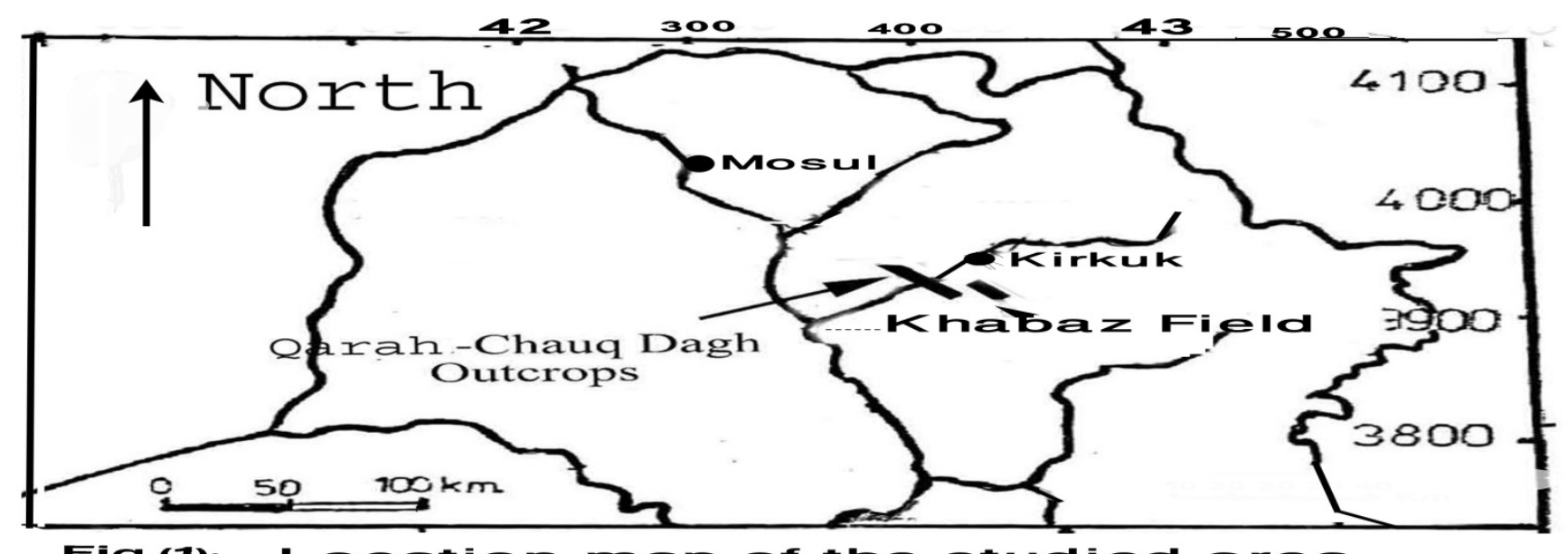

Fig. 1 : Location map of the studied area.

The importance data of the Miogypsinidae are discussed from the OligoceneMiocene carbonates (Azkand Formation) which are subdivided into four units (I, II, III and IV). Fig.(2).

\section{PREVIOUS RESEARCH}

Tan sin Hok visualised as early as in 1936 and 1937 the broad outlines of the scheme of evolution in the Miogypsinidae. The early works Miogypsinidae were reviewed by Drooger $(1952,1963)$, it has been well recognized that features which best show evolutionary change in the Miogypsinidae are in the embryonic -nepionic stage and hence classification could best be based upon these early developmental stages. Ujiie (1966) discussed the evolutionary lines of Miocene Miogypsinoides population from Japan by using parameters $\mathrm{x}, \gamma, \alpha$ and $\beta$. 
Evolutionary Aspects of the Miogypsinidae from Azkand ... 


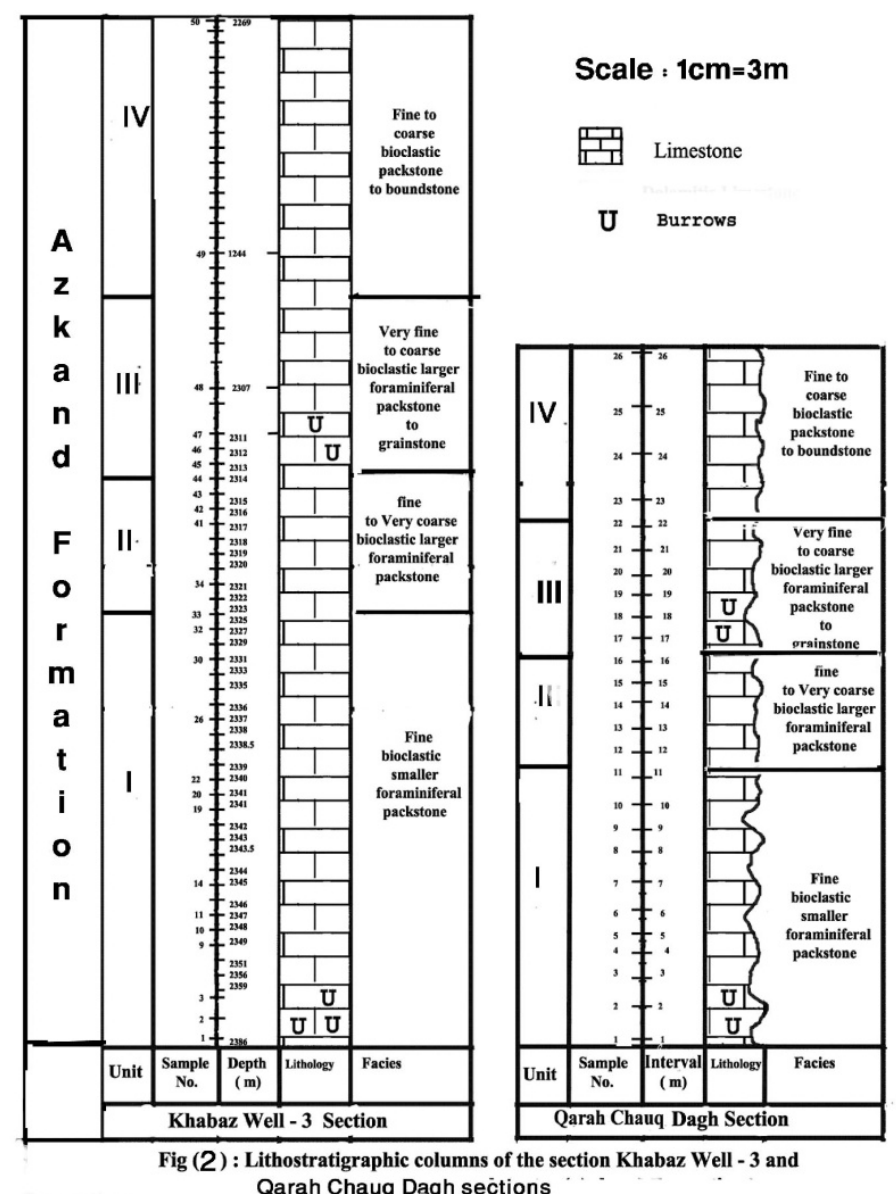

Fig. 2 : Lithostratigraphic columns of the section Khabaz Well- 3 and Qarah Chauq Dagh sections. 
Raju $(1974,1991)$ strictly following Drooger's method proposed the zonal scheme at the same time discussed phylogenitic trends from Kutch and Cauvery basins in India.

The detailed research on the phylogeny of Miogypsina made this genus a very useful tool for chronostratigraphic correlations, especially on regional scale (Drooger and Laagland, 1986).

A biometric research have been performed on Miogypsinids from north Italy by Mortara (1987) indicated strong correlation between $\mathrm{x}, \gamma, \mathrm{D}_{2} / \mathrm{D}_{1}$

The biometric analysis of Miogypsinidae with their evolutionary aspects investigated by Wildenborg (1991) near Mineo (Sicily) states that the morphometeric series of Miogypsina is not complete because of hiatuses in the local environment. Al-Omari and Sadek $(1972,1975)$ identified many Miogypsina from Iraq based on statistical study on Miogypsinidae associations.

\section{METHODS OF INVESTIGATION}

Drooger (1952, 1963 and 1993) has introduced a number of counts and measurements for Miogypsinidae species. Only the few characteristic parameters that define species are considered in this paper (Fig.3). These are:

(X): The total number of nepionic chambers in the initial spiral excluding the two embryonic chambers and including the closing chamber, if present.

$(\gamma)$ : This angular parameter is quantitative measure of the orientation of the nepiont in the foraminiferal test. A detailed description of the way of measuring $\gamma$ was given by Amato and Drooger (1969).

Two line segments determine this variable. The first one starts at the center of the protoconch and passes through the center of the deuteroconch and continues through the apex of the test, coinciding with the apical -frontal line. The zero of the $\gamma$-scale has been arbitrarily fixed at the configuration where both line segments coincide in individuals with one whorl or less.

$\gamma:$ is positive if the first principal auxiliary chamber points to the frontal margin of the test. Otherwise $\gamma$ is negative. In the later case it is measured by rotating the embryonic line segment in the direction of coiling towards the apical frontal line segments.

$(\boldsymbol{\alpha})$ : The arc length of the circumference of the protoconch underlying the shorter spiral.

( $\boldsymbol{\beta})$ : The arc length of the circumference of the protoconch underlying both protoconchal spirals .

(V): This parameter depends on two angular variables, $\gamma$ and $\beta$, in the following way: $\mathrm{V}=100 \alpha / 0.5 \beta=200 \alpha / \beta$.

The dimensionless ratio, which scale ranges from 0 to 100 indicates the degree of symmetry of the protoconchal spirals.

(D): The maximum diameter of the protoconch is measured perpendicular to the embryonic line and includes half of the thickness of the walls

$\left(\mathbf{D}_{2)}\right.$ : These parameters represent the largest diameter of the deuteroconch, determined parallel to the measurement line of $\mathrm{D}_{1}$.

(P): Percentage of specimens with two principle auxiliary chambers. 


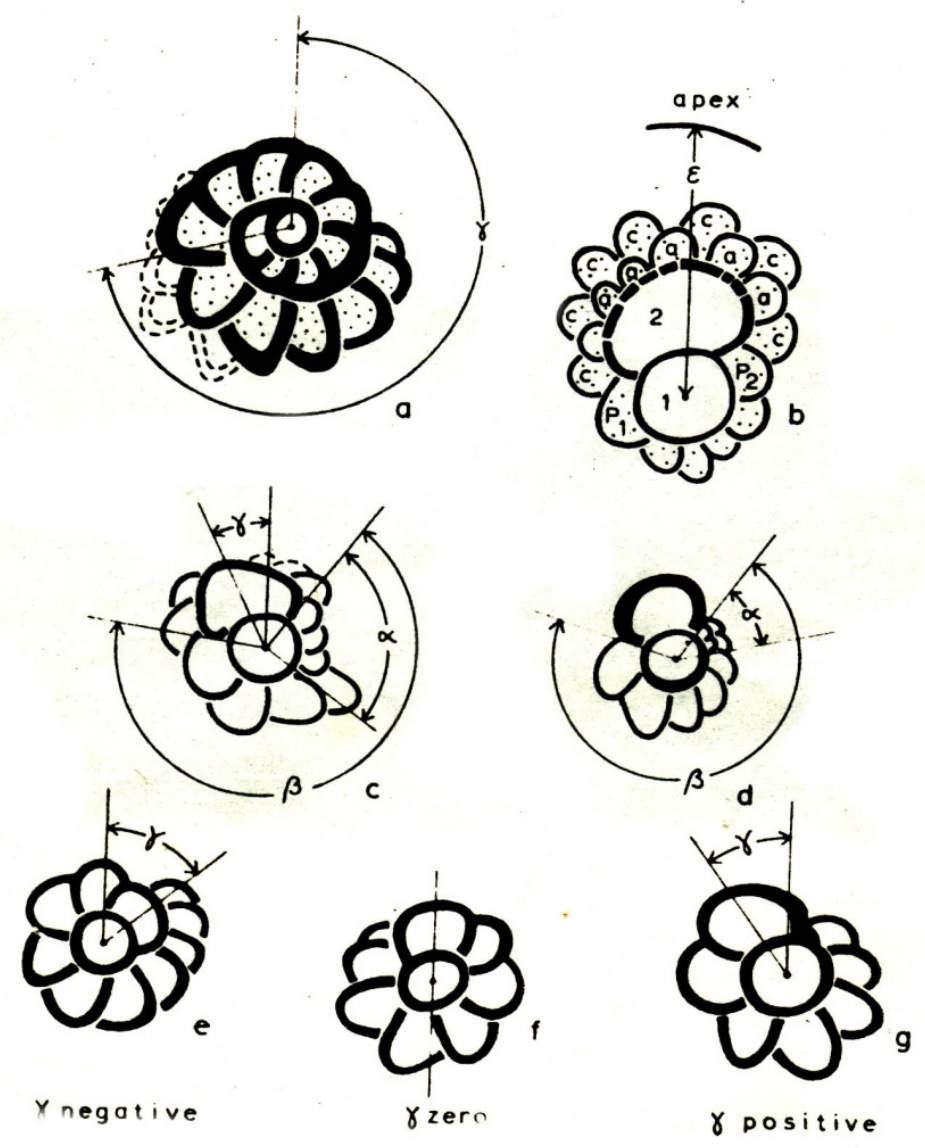

Fig. 3 : Schematic drawing the median sections of the embryonic-nepionic stage of

Miogypsinidae illustrating the derivation of $(\alpha, \beta$ and $\gamma) .1=$ protoconch, $2=$ deuteroconch. 1 and 2 constitute the embryonic stage; chambers around the embryonic stage (doted in figs. $\mathrm{a}, \mathrm{b}$ ) constitute the nepionic stage. $\mathrm{P}_{1}=$ first principal auxiliary chamber, $\mathrm{P}_{2}=$ second principal auxiliary chamber; $\mathrm{a}=$ accessory auxiliary chamber, $\mathrm{c}=$ closing chamber. (after Raju, 1974 and Drooger, 1993)

\section{THE DEVIATION FROM THE GENERAL DEVELOPMENT PATTERN IN MIOGYPSINA}

The two groups of Miogypsinoides specimens, both close to M. bantamensis are found to a company M.gunteri-tani in the Aquitanian carbonates of the Azkand Formation in Khabaz well-3 and Qarah Chauq Dagh sections. The two biometric units, Miogypsinoides I, and II, differ primarily in embryonic size and show relatively minor morphometric differences in nepionic configuration. The mean protoconch diameter of

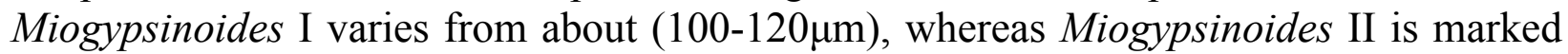
by a mean diameter of the protoconch of about $(210-220 \mu \mathrm{m})$. The chronostratigraphic range of Miogypsinoides I continues into the Late Aquitanian, where it associates the successive species Miogypsina gunteri, and Miogypsina tani. The Late Aquitanian Miogypsinoides I displays small shift in its nepionc variables with respect to its early Aquitanian ancestor; $(\mathrm{X})$ decreases from about (13 to 14) in the early Aquitanian to about (11 to 12 ) in the Late Aquitanian. A part from this shift that occurs close to the chronostratigraphical boundary, neither Miogypsinoides I nor Miogypsinoides II shows a 
significant net change in their nepionic variables. In both nepionic and embryonic characteristics Miogypsinoides I is very close to primitive Miogypsina gunteri, Miogypsinoides II display distinct morphological overlap with the other older Miogypsinoides complanata and with the Miogypsinoides formosensis. So far, the simultaneous existence of the type of Miogypsinoides in the Aquitanian is not known in the literature. Three hypotheses will be offered to explain the co-occurrences, first of all some remarks will be made on the habitats of both types on the basis of our own observations, the Miogypsinoides bantamensis probably preferred a hard substrate and some what shallower depth relative to Miogypsina s.s. as in Unit (IV) for both Aquitanian Miogypsinoides the whole rock thin sections gave no reliable indication on the paleoenvironment, especially because of the low frequencies in this interval. The biometric data on Miogypsinoides I, and II give possibly a clue to the relative position of the habitats of both units (III and IV) Figs. 4,5). In the successive samples of the Units (I and II) in both sections, the frequency of type II, relative to type I is the largest in the upper part of this unit which has been thought to represent the deeper facies of this interval, Thus, Miogypsinoides II seems to prefer shallower habitats with respect to Miogypsinoides I and also with respect to Miogypsina s.s. In contrast the low frequency distributions of Miogypsinoides II will be shown and clear in the units (III and IV) as compared to Miogypsinoides I which shows highly distribution.

According to (Wildenborg, 1991) the Chattian and early Aquitanian shows an excellent analogue of the differentiation in the Miogypsinoides and Miogypsina s.s ., as in the studied area early Miogypsinoides possibly split into two branches one with lateral chamber complexes (Miogypsina s.s.) and the other preserving the massive side walls of Miogypsinoides . Simultaneously, the Miogypsina s.s. branch underwent a reduction of the mean embryon size with respect to Miogypsinoides II, rather later still showing distinct increase of embryonic size with respect to the supposedly ancestral Miogypsinoides complanata and Miogypsinoides formosensis. 


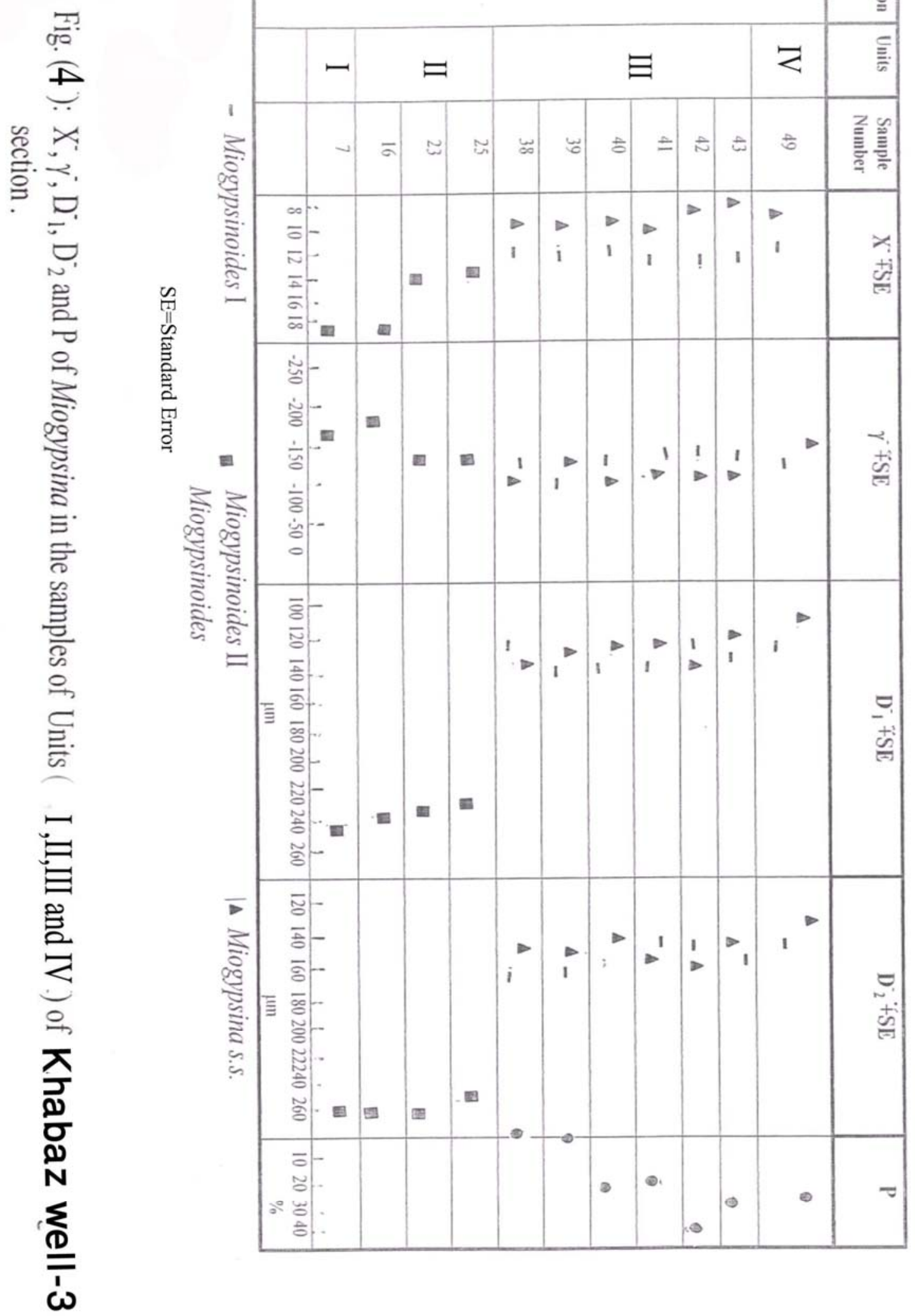




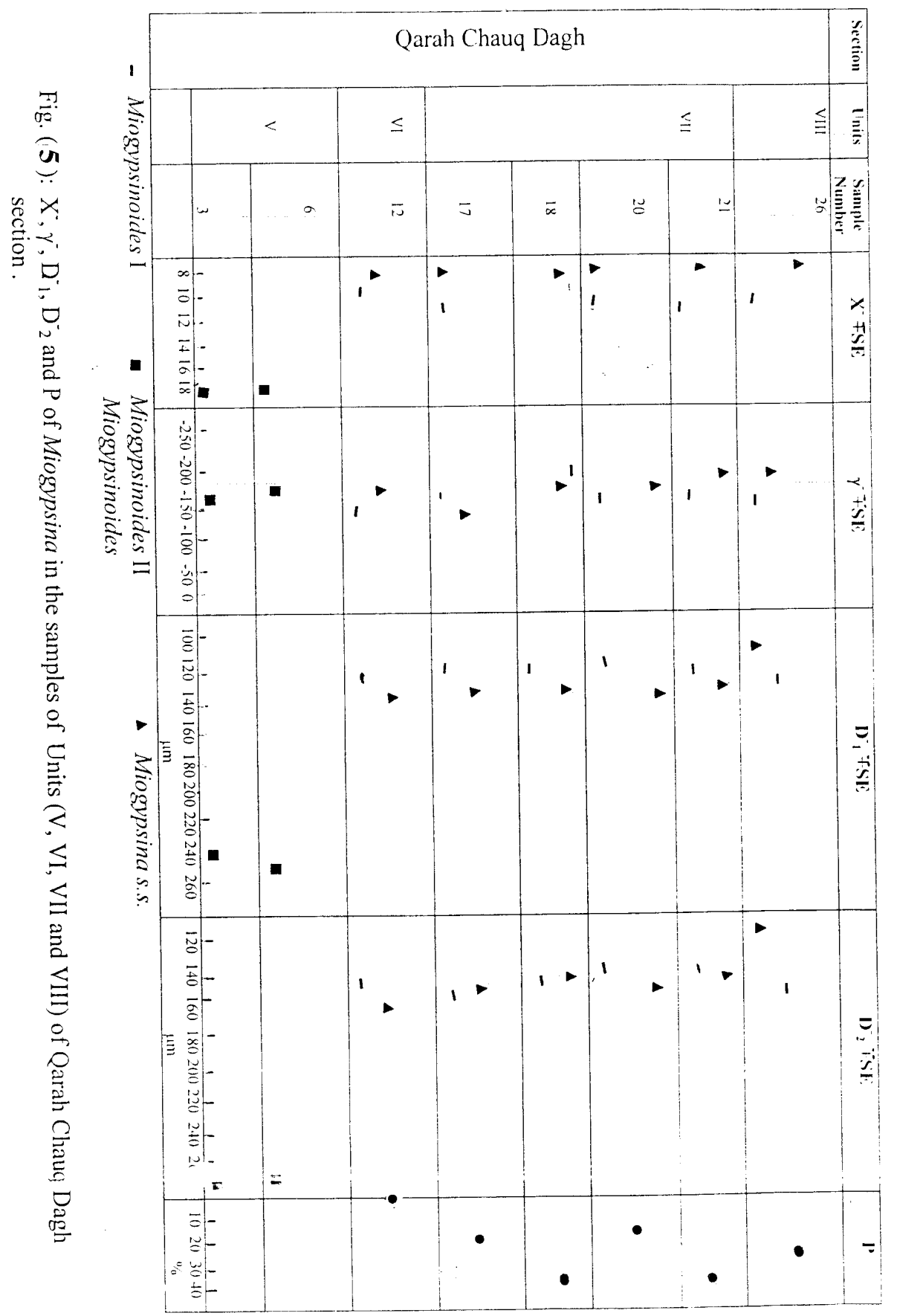


This splitting into two branches could well represent the adaption to specific habitats deeper than those of Miogypsinoides II. There is close resemblance between the embryons and nepionics of Miogypsinoides I the most primitive Miogypsina s.s. (Miogypsina gunteri). This brings us to explain the existence of Miogypsinoides $\mathrm{I}$ in the regions of the studied sections. Both taxa with small embryons would belong to one monophylogenitic group. Taking into account the probable difference in preference for the type of substrate, and may assume a case of different adaptive evolution, Miogypsinoides I would have adapted to hard substrate of some what greater depth, and this corresponds to the hypothesis proved by (Wildenborg, 1991). The $\left(\mathrm{D}^{-}{ }_{1}-\mathrm{X}^{-}\right)$and $\left(\mathrm{D}_{1}^{-}-\mathrm{V}^{-}\right)$scatter diagrams in figures (6 and 7$)$, illustrate that our associations of early Miogypsinoides and Miogypsina s.s. fit rather well within the range of the Miogypsina data from French, Italian and Sicily localities. They differ from the more southern occurrence in having in the whole larger mean protoconch sizes. However the Aquitanian, Miogypsinoides I is close to the Miogypsinoides associations from localities in Africa., viz Egypt (Souaya,1961); Morocco (Brönnimann,1940); Drooger,1954b.

In the preceding discussion, it has been presented to explain the types of Miogypsinoides in addition to Miogypsina s.s. . in the studied sections of Aquitanian. A local region of all taxa would invoke a rather complicated evolutionary exceeds or series of events in a time interval close to the chattian-Aquitanian boundary, Unfortunately, our record for this period is far from complete.

As seen in Figures. (6 and 7), we prefer the hypothesis of migration of Miogypsinoides I from a southern subprovince. There are good agreements to defend the postulate that the studied section was split into a northern and southern subprovince. The studied area that was part of the Africa realm with its specific evolution of Miogypsina. At some time during the early Aquitanian, Miogypsinoides I a typical form of the African subprovince, migrated into the studied area.

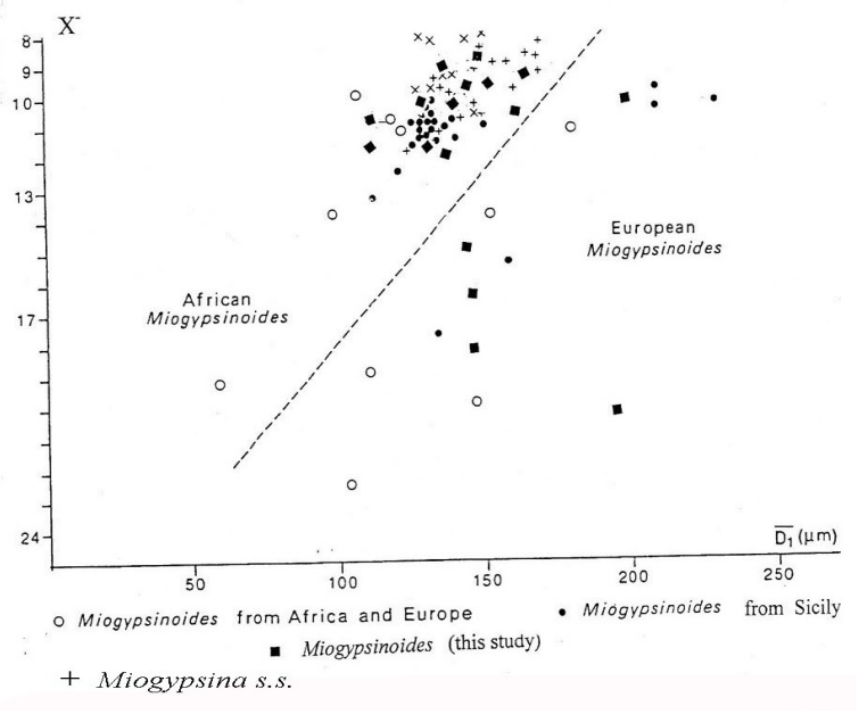

Fig. 6 : $\mathrm{D}^{-}{ }_{1}-\mathrm{X}^{-}$diagram of Miogypsinoides in the Khabaz well-3 and Qarah Chauq Dagh sections. Dashed lines separate Europian assemblages of Miogypsinoides from assemblages of African origin and assemblages from Sicily. (Literature data from Drooger and Raju,1973; De Mulder, 1975 and Wildenborg,1991). 


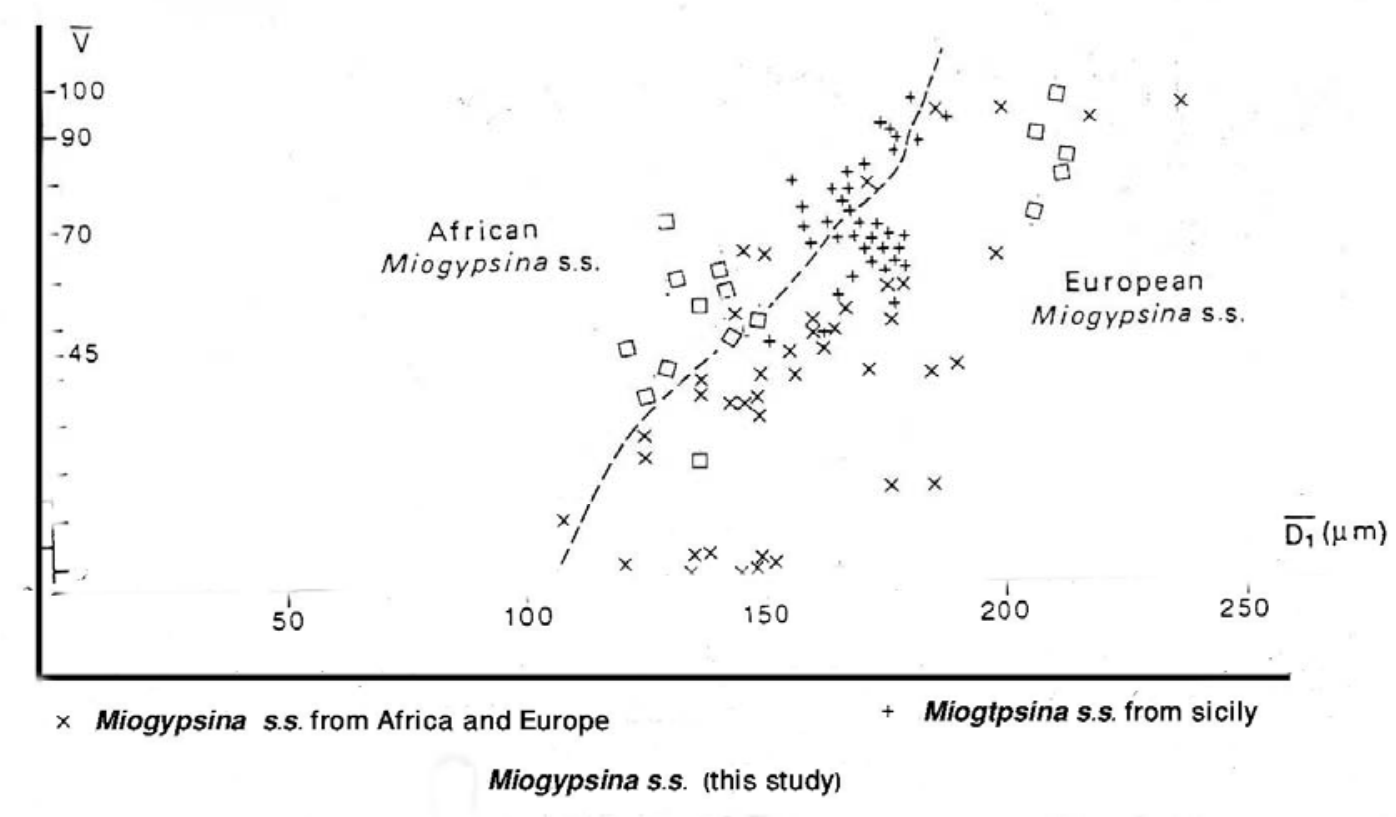

Figure 7 ' $\mathrm{D}_{1}^{-}-\mathrm{V}^{*}$ diagram of Miogypsna s.s. in the Khabaz well-3 and Qarah Dagh sections, Dashed lines separate European assemblages of Miogypsina s.s. from assemblages of African origin and assemblages of Sicily.(Literature data from Drooger \& Raju, 1973; Brun \& Wong, 1974; De Mulder, 1975 and Wildenborg, 1991)

\section{EVOLUTION IN MIOGYPSINOIDES}

Tan Sin Hock, 1936a, 1937; Barker and Grimsdale, 1937; Drooger, 1963) agree that Miogypsinoides evolved from a Rotalia-like ancestor (Pararotalia or Neorotalia), because of certain similarities between the individuals of M.complanata and associated Pararotalia. Raju, (1974) recorded that the Indian material for small individuals of both M.cf. bermudezi and M.complanata show several morphological characteristicsornamentation, trochospiral stage, umbilical plug-similar to those associated individuals of Pararotalia. These data leave little doubt that early Miogypsinoides evolved from a Pararotalia ancestor.

Drooger, (1984) discussed in detail the evolutionary patterns in Orbitoidal Foraminifera, in which he included Miogypsinidae with an available data and has attempted to explain evolutionary processes with reference to pulsating, this later term was used by Drooger and Raju, (1978), in explaining the succession of Miogypsinidae, in depending on the mean values of $(\mathrm{X})$ in encompassing the species. In the preceding discussion and as seen in table (1), it is clearly visible the gradual change in the mean values of $(\mathrm{X})$ progressively from the lower part to upper part of the Azkand Formation in Khabaz well-3 and Qarah Chauq Dagh sections, in the lower most Units (I and II) reflect 
individuals with large embryon size with mean values of (X) ranging between (19-13) which indicate to Miogypsinoides complanata and Miogypsinoides formosensis respectively. The occurrence of these species with other associated foraminifera includes Lepidocyclina. morgani which is an indication for Late Oligocene (Chattian) (Drooger and Raju, 1973). In Unit (III), consists two groups of Miogypsinoides individuals, the two biometric units, Miogypsinoides I and II, differ primarily in embryonic size, the mean protoconch diameter of Miogypsinoides I varies from about $(110$ to $120 \mu \mathrm{m})$ whereas Miogypsinoides II is marked by $(210$ to $230 \mu \mathrm{m})$ and their mean values of X varies between (13-10), both of species close to Miogypsinoides bantamensis, type II assemblages are classified as M.ex. interc. bantamensis -dehaartii and those of type I are named M.ex.interc. formosensis-bantamensis, co-occurring with Miogypsina gunteri-tani, the appereance of these species give indication to the Early Aquitanian. The Miogypsinoides types I range up into the unit (IV) with mean values of (X) differ between (11-13) are mainly close to Miogypsinoides bantamensis. (Table 1, Fig. 8).

Table 1 : Species list of Miogypsinoides and pertinent, biometric data; N=Number of observations on $\mathrm{X}$ in a sample or a sample suite; if $\mathrm{N}<11$, then the name is presented in parenthese, $\mathrm{SE}=$ Standard Error

\begin{tabular}{|c|c|c|c|c|l|}
\hline Section & Sample & $\mathbf{X}^{-}$ & $\mathbf{S E}$ & $\mathbf{N}$ & $\begin{array}{l}\text { Miogypsinoides } \\
\text { Ex. interc. }\end{array}$ \\
\hline Khabaz well-3 & \multicolumn{5}{|l|}{} \\
\hline & 49 & 12.3 & 0.35 & 13 & bantamensis \\
\hline & 43 & 12.3 & 0.30 & 15 & bantamensis \\
\hline & 42 (Type II) & 10.5 & 0.23 & 14 & bantamensis-dehaartii \\
\hline & 42 (Type I) & 12.3 & 0.23 & 18 & formosensis-bantamensis \\
\hline & 41 & 12.3 & 0.36 & 12 & bantamensis \\
\hline & 40 & 12.6 & 0.27 & 15 & bantamensis \\
\hline & 39 & 12.4 & 0.26 & 15 & bantamensis \\
\hline & 38 & 12.3 & 0.27 & 18 & bantamensis \\
\hline & 25 & 15.1 & 0.25 & 17 & formosensis \\
\hline & 23 & 15.3 & 0.27 & 15 & formosensis \\
\hline & 16 & 19.3 & 0.27 & 15 & complanata \\
\hline & 7 & 18 & 0.32 & 14 & complanata \\
\hline & 26 & & & & \\
\hline & 21 & 11.6 & 0.31 & 14 & bantamensis \\
\hline & 20 & 11.7 & 0.29 & 14 & bantamensis \\
\hline & $18($ Type II) & 10.4 & 0.31 & 18 & bantamensis-dehaarti \\
\hline & $18($ Type II) & 11.4 & 0.27 & 17 & formosensis-bantamensis \\
\hline & 17 & 11.9 & 0.30 & 15 & bantamensis \\
\hline & 12 & 12.6 & 0.33 & 15 & formosensis \\
\hline & 6 & 19.8 & 0.34 & 12 & complanata \\
\hline & 3 & 19.1 & 0.31 & 12 & complanata \\
\hline & & & &
\end{tabular}


Fig. 8 : Evolution of Miogypsinoides from the Units (I, II, III and IV) of the sections Khabaz well- ${ }_{3}$ and Qarah Chaug Dagh.

\section{EVOLUTION IN MIOGYPSINA S.S.}

In this and many earlier investigation it is the variable $\left(\mathrm{V}^{-}\right)$that has been used to describe the nepionic evolution of Aquitanian Miogysina s.s. and to identify the successive biometric species (Wildenborg, 1991). (Fig. 9) 
It has been suggested that the diameter of the protoconch may change in relation to water depth or some depth linked factor. According to theory (Drooger and Raju, 1973) protoconch diameter would increase toward greater depth. If, furthermore some correlation would exist between embryonic size and nepionic parameters, such ecological factors could indirectly have affected the values of $(\mathrm{V})$ and $\left(\mathrm{V}^{-}\right)$. An examination of the intra - and intersample correlations between the embryonic and nepionic variables is needed to evaluate this constraint.

Fig. 9 : Frequency of Miogypsina s.s. in Units (I, II, III and IV) and shifts in V' and D' illustrating the supposed relation between low frequency zones and evolutionary change the lines (1-6) change in faunal composition.

Our discussion is that the positive correlation between $\left(\mathrm{V}^{-}\right.$and $\left.\mathrm{D}_{1}^{-}\right)$probably is not the result of functional relations between both statistics. If the mean size of the embryon 
was some how determined by a depth linked ecological factors, this effect probably was not reflected in parameter $\left(\mathrm{V}^{-}\right)$. On the contrary the supposed shallowing during the deposit of unit (II) would theoretically have caused a decrease in $\left(\mathrm{D}^{-}\right)$instead of the general increase that we found. We think that we can role out the effects of environment on the succession of $\left(\mathrm{V}^{-}\right)$values. This inclusion is in good harmony with the fact that intrasample $\left(\mathrm{V}^{-}-\mathrm{D}_{1}^{-}\right)$correlations are hardly ever of statistical significance.

According to certain evolutionary theories, we need low frequency populations for rapid changes in morphology. As a check on such a possible relation we plotted the relative frequency of Miogypsina s.s. in the Fig. (9) which shows two low frequency zones of Miogypsina s.s. have been entered the lowest ( $\left.\mathrm{V}^{-}\right)$in Unit (II) are found in the low frequency interval between level (3) and (4) and correspond to a negative change followed by a leap forward at the top. We can not exclude the possibilities that the reworking of older Miogypsina s.s. must be held responsible for the negative shift. Also $\left(D_{1}\right)$ shows a set back have way this lower most zone of low relative numbers. With increasing frequencies of Miogysina s.s. across level 4 is shown a notable increase, decrease and weak increase again into the middle low frequency zone followed by a staggered increase across level (6) toward the top, of unit (III). And the second low frequency interval is noted after level (6) toward the upper part of Unit (III).

The early frequency of Miogypsina s.s. has been seen across between levels (1) and (2) in unit (II) of Azkand Formation in Khabaz well-3 and Qarah Chauq Dagh sections correspond to the primitive type of Miogypsina associations with old Chattian Miogypsinoides complanata and Miogypsinoides formosensis with mean (X) values of these species range between (9-12).

The other increasing infrequency of Miogypsina s.s. has been seen across the level (6), especially in the top of Unit (III), which is characterized by the simultaneous occurrence of Miogypsinoides and Miogypsina s.s. in samples of Unit (III) and these species possess the mean values of $X$ varies between (9-11). This frequency of Miogypsina s.s. are chosen to Miogypsina gunteri-tani. (Fig. 10, Table 2).

Table 2 : List of identified, biometric species of Miogypsina s.s. and relevant, statistical data, $\mathrm{N}=$ number of observations on $\mathrm{X}$ in one sample; $\sigma \mathrm{p}$ standard deviation of $\mathrm{p}$. $\mathrm{SE}=$ Standard error

\begin{tabular}{|c|c|c|c|c|c|c|c|}
\hline Section & Sample & $\mathbf{X}^{-}$ & SE & $\mathbf{N}$ & $\mathbf{P \%}$ & бp & $\begin{array}{l}\text { Miogypsina/ } \\
\text { M.ex. interc. }\end{array}$ \\
\hline \multicolumn{8}{|c|}{ Khabaz well-3 } \\
\hline & 49 & 9.51 & 0.46 & 12 & 25 & 1.6 & gunteri-tani \\
\hline & 43 & 9.4 & 0.44 & 11 & 28 & 1.45 & gunteri-tani \\
\hline & 42 & 10.1 & 0.36 & 15 & 35 & 1.41 & gunteri \\
\hline & 41 & 10 & 0.35 & 14 & 21 & 1.41 & gunteri \\
\hline & 40 & 10.8 & 0.41 & 13 & 23 & 1.36 & gunteri \\
\hline & 39 & 10.5 & 0.37 & 11 & 0 & 1.1 & gunteri \\
\hline & 38 & 11 & 0.48 & 12 & 0 & 1.54 & gunteri \\
\hline \multicolumn{8}{|c|}{ Qarah Chauq Dagh } \\
\hline & 26 & 9.1 & 0.35 & 12 & 25 & 1.32 & gunteri-tani \\
\hline & 21 & 9.7 & 0.37 & 13 & 24 & 1.32 & gunteri-tani \\
\hline & 20 & 10.3 & 0.36 & 14 & 15 & 1.27 & gunteri \\
\hline
\end{tabular}




\begin{tabular}{|ccccccc|}
\hline 18 & 10.4 & 0.38 & 13 & 34 & 1.15 & gunteri \\
\hline 17 & 10.3 & 0.3 & 12 & 17 & 1.31 & gunteri \\
\hline 12 & 10.3 & 0.40 & 12 & 0 & 1.37 & gunteri \\
\hline
\end{tabular}

In summary, we may suggest that there was some link in the evolution of our Chattian, Aquitanian, Miogypsina s.s., to episodes with low frequencies of this subgenus. Evolutionary changes seem to be of subordinate importance in the periods in between, when Miogypsina was relatively more frequent.

\section{CONCLUSION}

The evolutionary trend in Miogypsina based on the gradual changes in the mean values (X), the early frequency of Miogypsina gunteri with the mean values $(X=9-12)$ recorded from the lower part of the Azkand Formation in both sections associated with old Chattian Miogypsinoides complanata and Miogypsinoides formosensis with their mean values of (X-) between (13-17) but the Miogypsina gunteri-tani with their ( $\left.\mathrm{X}^{-}\right)$ values about (9-11) has occurred in the upper part of Azkand Formation (Early Aquitanian), Simultaneously with Miogypsinoides bantamensis with their mean values of $\left(\mathrm{X}^{-}\right)$about (10-13).

\section{REFERENCES}

Amato, V. and Drooger, C.W., 1969. How to Measure the Angle $\gamma$ in the Miogypsinidae. Rev. Esp. Micropal., Vol. 1, pp.19-24.

Al-Omari, F.S. and Sadek, K., 1972. Occurrence of Miogypsina (s.s.) in Lower Fars Formation from Northern Iraq (Bashiqa area). J. Geol. Soc. Iraq., Vol. V, 313 p.

Al-Omari, F.S. and Sadek, K., 1975. Contribution to the Miocene of Northern Iraq by Means of Miogypsinoides. Revista Espanaóla, de Micropaleontologia, Nümero, Espessial, Enero, pp.37-42.

Barker, R.W. and Grimsdale, T.F., 1937. Studies of Mexican Fossil Foraminifera Ann. and Mag. Nat. History, s. Vol.10.

Bronimann, P., 1940. Über Die Tertiären Orbitoidider Und Die Mioypsiniden Von Northwest-Narokko. Schweiz. Pal. Abh., Band, Vol. 63, pp.1-113.

De Mulder, E.F.J., 1975. Microphona and Sedimentary Tectonic History of the OligoMiocene of the Joniane Islamnd and Western Europe (Greece). Ulrecht. Micropal. Bull., Vol. 13, 140 p.

Drooger, C.W., 1952. Study of American Miogypsinidae. Ph.D. Thesis Univ.Utrecht, pp. $1-80$.

Drooger, C.W., 1954. Miogypsina in Northwestern Moroco. Proc. Kon. Ned. Akad. Wet., ser. B, Vol. 57, pp.580-591.

Drooger, C.W., 1963. Evolutionary Trends in Miogypsinidae. Evol. Trends in Foram., Elsevier Amsterdam, pp.315-349.

Drooger, C.W., 1984. Evolutionary Patterns in Lineages of Orbitoidal Foraminiferak on. Ned. Akad. Wet. , ser. B, Vol. 87, pp.103-130.

Drooger, C.W., 1993. Radial Foraminifera Morphometrics and Evolution, Vrhamd, Kon. Ned. Akad. Wetensch. Amesterdam, pp.1-241.

Drooger, C.W. and Laagland, H.M., 1986. Larger Foraminiferal Zonation of the Europian-Mediteeriane Oligocene. Proc. Kon. Ned. Akad. Wet., ser. B, Vol. 189, pp.135-148. 
Drooger, C.W. and Raju, D.S.N., 1973. Protoconch Diameter in the Miogypsinidae. Proc. Kon. Ned. Akad. Wet., ser. B, Vol. 76, pp.206-216.

Drooger, C.W. and Raju, D.S.N., 1978. Early Miogypsinoides in Kutch, Western India. Proc. Kon. Ned. Akad. Wet., ser. B, Vol. 81, pp.186-210.

Mortara, E.F., 1987. Miogypsinid dell aerie Oligo-Miocenica Dellacollino Della Societē Di Tornio (Italia Nord-Occidentale) Paleontologica, Italiana, Vol. 26, No. (1-2), pp.119-150.

Raju, D.S.N., 1974. Study of Indian Miogypsinidae. Utrecht Micropal. Bull. Serv. Geol., Vol. 9, 149 p.

Raju, D.S.N., 1991. Miogypsina Scale and Indian Chronostratigraphy. Geoscience Journal, Vol. (XII), No. 1, pp.53-65.

Souaya, F.J., 1961. Contribution to the Study of Miogypsina s.1. from Egypypt. I/II statistical Investigations / III General Conclusions. Proc. Kon. Ned. Akd. Wet., ser. B, Vol. 64, pp.665-705.

Tan Sin Hok., 1936. Zur Kenntnis Der Miogypsiniden. De Ingenieur in Ned. Indië, Jaarg. Vol. 3, No. 3, pp.45-61. No.5, pp.84-98, No. 7, pp.109-123.

Tan Sin Hok., 1937. Weiere Untersuchungen Über Dic Miogypsiniden. Delngenieur in Ned. Indië, jaarg. Vol 14, No.3, pp. 33-45, No.6, pp.87-111.

Ujiie, H., 1966. Evolutionary Line of Miocene Miogypsinid Populations- Restudy of the Japanes Miogypsinoides part 2. Bull. Nut. Sci. Mus. Tokyo, Vol. 9, No. 3.

Wildenborg, A.F., 1991. Evolutionary Aspects of the Miogypsinids in the Oligo-Miocene Carbonates Near Mineo (Sicily), Printed in the Netherlands, 44figs., 6 plates, 140 p. 